\title{
ANALISIS KESULITAN BELAJAR MENGGUNAKAN E-LEARNING TERHADAP PEMAHAMAN KONSEP MATEMATIKA SISWA MA QAMARUL HUDA
}

\author{
Moh.Supratman ${ }^{1}$, Nurhasmah ${ }^{2}$ \\ Universitas Qamarul Huda Badaruddin \\ 18supratman@gmail.com
}

\begin{abstract}
ABSTRAK
E-Learning adalah suatu sistem pembelajaran yang dapat digunakan sebagai sarana untuk proses belajar mengajar yang dilaksanakan tanpa harus bertatap muka secara langsung antara guru dengan siswa, namun ketika pengunaan e-learning terlalu sulit kemungkinan siswa tidak mampu belajar secara maksimal, begitu pula ketika banyaknya data yang harus disampaikan tetapi adanya kendala teknis seperti jaringan yang lambat dan kurangnya sarana dan prasarana pendukung yang dimuliki siswa tentu saja dapat menjadi penghambat aktivitas siswa. Penelitian ini bertujuan untuk mengetahui kesulitan belajar siswa terhadap pemahaman konsep matematika dengan menggunakn e-learning. Metode penelitian yang digunakan adalah metode penelitian deskriptif. Sampel penelitian ini adalah siswa kelas XII MA Qamarul Huda yang berjumlah 30 orang siswa. Instrument yang digunakan untuk mengumpaulkan data adalah instrument angket respon siswa yang disebar meggunakn Google form yang berjumlah 31 item. Berdasarkan hasil analisis data rata-rata pencapaian respon siswa mengenai kesulitan belajar menggunakan e-learning terhadap pemahaman konsep matematika yaitu $75 \%$ dengan nilai pencapaian terendah yaitu pelaksanaan interaksi, tugas dan bahan ajar sebesar $73 \%$ dan indikator yang paling tinggi dicapai siswa yaitu kendala teknis signal dan ketidak mampuan dalam belajar mengunakan e-learning sebesar $77 \%$.
\end{abstract}

Kata Kunci: Kesulitan Belajar Matematika, e-learning

\section{LATAR BELAKANG}

Adanya pandemi Covid-19 yang melanda seluruh dunia termasuk Indonesia membuat pemerintah menerapkan kebijakan ketat untuk memutus rantai penyebaran Covid-19. Salah satu caranya adalah dengan melakukan pembatasan interaksi masyarakat yang diterapkan dengan istilah phisycal distancing. Namun, kebijakan physical distancing tersebut dapat menghambat laju pertumbuhan dalam berbagai bidang kehidupan, baik bidang ekonomi, sosial, dan tentu saja pendidikan. Keputusan pemerintah untuk meliburkan para peserta didik, memindahkan proses belajar mengajar di sekolah menjadi di rumah dengan menerapkan kebiakan Work From Home (WFH) membuat resah banyak pihak.

Kebijakan WFH tertuang dalam surat edaran menteri pendayagunaan aparatur Negara dan Reformasi Birokrasi (PAN \& RB) nomor 50 tahun 2020 tentang perubahan kedua nomor 19 tahun 2020 tentang penyesuaian sistem kinerja aparatur sipil Negara dalam upaya pencegahan penyebaran covid-19 di lingkungan instansi pemerintah dan 
guru dalam upaya melaksanakan proses pembelajaran perlu dilakukan secara online atau dalam jaringan (daring).

E-Learning adalah suatu sistem pembelajaran yang dapat digunakan sebagai sarana untuk proses belajar mengajar yang dilaksanakan tanpa harus bertatap muka secara langsung antara guru dengan siswa (Ardiansyah, 2013). E-learnig pada pelaksanaannya membutuhkan dukungan perangkat-perangkat mobile seperti telpon, tablet dan laptop yang dapat digunakan untuk mengakses informasi dimana saja dan kapan saja (Gikas \& Grant, 2013). Dalam (Adijaya, 2018) dikatakan pembelajaran online atau pembelajaran dalam jaringan (daring) dianggap sebagai paradigma baru dalam proses pembelajaran karena dapat dilakukan dengan mudah tanpa harus bertatap muka di suatu ruang kelas dan hanya mengandalkan sebuah aplikasi berbasis koneksi internet maka proses pembelajaran dapat berlangsung.

Manfaat dari kegiatan belajar menggunakan e-learning yaitu dapat mempersingkat waktu pembelajaran dan membuat biaya pelajaran lebih ekonomis, dapat mempermudah interaksi siswa dengan bahan materi yang telah diberikan, dapat saling berbagi informasi dan dapat mengakses bahan belajar setiap saat hingga berulang-ulang, dan merupakan proses pengembangan pengetahuan yang tidak hanya terjadi di dalam ruangan kelas saja, tetapi diluar kelas atau dirumah (study at home) dengan bantuan peralatan teknologi dan jaringan internet, sehingga para siswa dapat lebih aktif terlibat dalam proses belajar mengajar (Rohmah, 2016). Meskipun demikian, manfaat pembelajaran mengunakan e-learning memiliki banyak kekurangan antara lain; kurangnya interaksi antara guru dansiswa, sehingga bisa memperlambat terbentuknya penilaian serta penalaran dalam proses belajar mengajar. Adanya kecendrungan mengabaikan aspek akademik maupun aspek sosial, dan proses belajar mengajarnya lebih kearah pelatihan daripada kependidikan dan maoritas siswa tidak memiliki motivasi belajar e-learning terutama dalam belajar matematika (yazdi, 2012).

Puspaningtyas (2019) menyatakan bahwa matematika merupakan salah satu cabang ilmu pengetahuan yangdipelajari disekolah. Pelajran matematika tidakmelulu tentang angka. Banyak kemampuan yang bisa dikembangkan dari pelajran matematika antar lainpeyelesaian masalah, komunikasi matematis, dan koneksi matematis. Oleh karena itu diharapkan pelajaran matematika menjadi salah satu pelajaran yang menyenangkan untuk siswa. Namun matematika selalu diangap sulit bagi siswa karena objek matematika yang abstrak menggunakan banyak rumus sehingga pandangan siswa terhadap pelajaran matematika di sekolah merupakan pelajaran yang sulit dan rumit untuk diterapkan dan dipahami, hal ini serupa dengan apa yang dungkapkan oleh (Rusefendi, 2006) bahwa matematika merupakan salah satu pelajaran yang sulit dan rumit untuk diterapkan dan dipahami. Hal ini terjadi karena mayoritas guru masih menggunakan pembelajaran secara konvensional. Seharusnya guru sebagai perencana pembelajaran dituntut untuk merancang dan mengembangkan erbagai jenis media pembelajaran dan sumber belajar agar proses pembelajaran berlangsung secara efetif dan efesien terutama dalam memanfaatkan pembelajaran berbasis $e$-learning.

Berdasarkan latar belakang tersebut di atas, penelitian ini bertujuan untuk mengetahui kesulitan belajar menggunakan e-learning terhadap pemahaman konsep matematika siswa MA Qamarul Huda tahun pelajaran 2020/2021. 


\section{METODE PENELITIAN}

Penelitian ini menggunakan metode penelitian deskriptif yaitu tidak membuat perbandingan variabel dan sampel yang lain, dan mencari hubungan variabel itu dengan variabel yang lain (Sugiyono, 2016). Penelitian ini dilaksanakan untuk mengetahui (1) Bagaimakah hasil analisis kesulitan belajar menggunakan e-learning terhadap pemahaman konsep matematika siswa?, (2) Bagaimanakah respon kesulitan belajar menggunakan e-learning siswa terhadap pemahaman konsep matematika siswa?.

Penelitian ini dilaksanakan pada bulan Oktober-November 2020. Sampel atau subjek penelitian ini adalah siswa kelas XII MA Qamarul Huda yang berjumlah 30 orang siswa. Instrument yang digunakan dalam pengumpulan data adalah dengan menggunakan angket respon siwa yang disebar menggunakan Google form. Angket respon siswa tersebut berisi 31 item pernyataan yang mengukur respon siswa mengenai kesulitan belajar menggunakan e-learning terhadap pemahaman konsep matematika.

Skala pengukuran yang digunakan dalam penelitian ini adalah skala likert yang terdiri dari Sangat setuju (SS), Setuju (S), Tidak setuju (TS), dan Sangat Tidak Setuju (STS). Berikut kisi-kisi instrument disajikan dalam tabel berikut:

Tabel 1. Kisi-kisi instrument analisis kesulitan belajar matematika siswa

\begin{tabular}{|c|c|c|c|c|}
\hline \multirow[t]{2}{*}{ No } & \multirow[t]{2}{*}{ Indikator } & \multicolumn{2}{|c|}{ No Butir } & \multirow[t]{2}{*}{ Jumlah } \\
\hline & & $\begin{array}{c}\text { Item } \\
\text { Favourable }\end{array}$ & $\begin{array}{c}\text { Item } \\
\text { Unfavourable }\end{array}$ & \\
\hline 1 & $\begin{array}{l}\text { Kendala teknis yang } \\
\text { mempengaruhi ketidak } \\
\text { mampuan dalam } \\
\text { pembelajaran e-learning }\end{array}$ & 1,4 & $2,3,4$ & 5 \\
\hline 2 & $\begin{array}{l}\text { Melakukan } \\
\text { pembelajaran, interaksi, } \\
\text { tugas dan bahan ajar } \\
\text { dalam pembelajaran } e \text { - } \\
\text { learning }\end{array}$ & $6,7,9,10,13,18,19$ & $8,11,12,14,15,16,17$ & 14 \\
\hline 3 & $\begin{array}{l}\text { Stakeholder yang } \\
\text { membantu pelaksanaan } \\
\text { pembelajaran } e \text {-learning }\end{array}$ & $\begin{array}{c}20,22,23,24,25,26,27 \\
28,29,30\end{array}$ & 21 & 12 \\
\hline & Jumlah & 20 & 11 & 31 \\
\hline
\end{tabular}

\section{HASIL DAN PEMBAHASAN}

Untuk mengetahui tentang kesulitan belajar menggunakan e-learning terhadap pemahaman konsep matematika siswa MA Qamarul Huda tahun pelajaran 2020/2021, maka dilakukan analisis skor kesulitan penggunaan e-learning terhadap siswa ntuk tiap indikator sebagaimana disajikan dalam tabel 2 berikut:

Tabel 2. Pencapaian indikator kesulitan belajar menggunakan e-learning 


\begin{tabular}{|l|l|c|c|c|}
\hline No & \multicolumn{1}{|c|}{ Indikator } & $\begin{array}{c}\text { Skor yang } \\
\text { Dicapai }\end{array}$ & $\begin{array}{c}\text { Skor } \\
\text { Total }\end{array}$ & $\begin{array}{c}\text { Pencapaian } \\
(\%)\end{array}$ \\
\hline 1 & $\begin{array}{l}\text { Kendala teknis yang mempengaruhi } \\
\text { ketidak mampuan dalam pembelajaran } \\
\text { e-learning }\end{array}$ & 2307 & 3000 & 77 \\
\hline 2 & $\begin{array}{l}\text { Melakukan pembelajaran, interaksi, } \\
\text { tugas dan bahan ajar dalam } \\
\text { pembelajaran e-learning }\end{array}$ & 6118 & 8400 & 73 \\
\hline 3 & $\begin{array}{l}\text { Stakeholder yang membantu } \\
\text { pelaksanaan pembelajaran e-learning }\end{array}$ & 5429 & 7200 & 75 \\
\hline \multicolumn{2}{|c|}{ Rata-rata Pencapaian } \\
\hline
\end{tabular}

Berdasarkan tabel diatas diketahui rata-rata pencapaian indikator kesulitan belajar siswa menggunakan e-learning sebesar $75 \%$ dan indikator kesulitan yang paling tinggi adalah pada indikator kendala teknis yang mempengaruhi ketidakmampuan siswa dalam pembelajaran e-learning yaitu sebesar $77 \%$.

Berdasarkan hasil tersebut diatas menunjukkan adanya tingkat kesulitan belajar yang dihadapi siswa dengan menggunakan e-learning terutama pada kendala teknis seperti kurangnya akses internet yang kuat, banyaknya siswa yang belum memiliki handphone atau android sebagai penunjang terlaksananya pembelajaran menggunakan e-learning. Selain itu hasil tersebut menunjukkan masih rendahnya kemajuan belajar yang dicapai siswa jika dibanding dengan sistem pembelajaran langsung. Berikut dapat dilihat kesulitan belajar e-learning siswa sebagaimana disajikan dalam gambar 1 berikut:

\begin{tabular}{|c|c|c|c|}
\hline $\begin{array}{l}\text { Siswa sering } \\
\text { mengalami kendala } \\
\text { terkait dengan teknis } \\
\text { seperti kurangnya akses } \\
\text { internet }\end{array}$ & $\begin{array}{l}\text { Jumlah tugas yang } \\
\text { banyak membuat } \\
\text { siswa kesulitan dalam } \\
\text { mengerjakan pelajaran } \\
\text { matematika }\end{array}$ & $\begin{array}{l}\text { Siswa kurang mau } \\
\text { belajar mandiri }\end{array}$ & $\begin{array}{l}\text { Siswa kurang } \\
\text { memahami } \\
\text { tentang } \\
\text { pembelajaran } \\
\text { menggunakan } e \text { - }\end{array}$ \\
\hline
\end{tabular}

Gambar 1. Kesulitan belajar e-learning siswa

Adanya perubahan konsep pembelajaran dari pembelajaran secara langsung menjadi e-learning memang tidaklah mudah untuk mengubah kebiasaan tersebut dalam kegiatan belajar mengajar. Berbagai kendala yang muncul dari sistem pembelajaran langsung menjadi sistem e-learning kiranya dapat membantu pendidik yang berkompeten dalam menyusun suatu perencanaan sehingga proses terhadap pembelajaran terkait dengan adanya perubahan tersebut dapat dilakukan secara lebih baik dan lebih terencana.

Adapun solusi untuk mengatasi kesulitan belajar menggunakan e-learning terhadap pemahaman konsep matematika siswa, pendidik harus memberikan pemahaman kepada siswa bahwa pembelajaran menggunakan e-learning adalah menarik dan menyenangkan, dan pemenuhan sarana dan prasarana penunjang pelaksanaan pembelajaran menggunakan e-learning harus terpenuhi. 


\section{KESIMPULAN}

Berdasarakan hasil analisis terhadap kesulitan belajar menggunakan e-learning terhadap kemapuan matematika siswa dapat disimpulkan bahwa e-learning dapat membantu siswa dalam menguasai materi sehingga materi yang diajarkan dapat dipahami dengan baik, sehingga memberikan pengaruh yang positif dan terjadinya peningkatan hasil belajar, sikap dan kinerja siswa dapat terjadi peningkatan pemahaman siswa pada materi yang sudah dipelajari. Namun, ketika e-learning terlalu rumit mungkin siswa tidak mampu belajar matematika secar maksimal, terlebih lagi ketika banyak data yang harus disampaikan tetapi akses internet atau jaringan menjadi lambat, hal tersebut tentu dapat mengganggu aktifitas siswa.

Saran dalam penelitian ini yaitu pengelolaan waktu perlu dipertimbangkan lagi dalam setiap pelaksanaan model pembelajaran, sehingga semua aktivitas siswa diharapkan dapat dikembangkan sesuai dan harus memperhatikan kesiapan sarana dan prasarana penunjang pelaksanaan pembelajaran menggukan $e$-learning dengan tujuan pembelajaran dan pendidik harus memahami pembelajaran e-learning agar pembelajaran dapat terlaksana secara efektif, sehingga harapan kualitas pembelajaran dapat menjadi meningkat.

\section{DAFTAR PUSTAKA}

Dewi, P.S., Septa, H.W (2019). Peningkatan Kemampuan Pemecahan Masalah dan Disposisi Matematis Siswa dengan Pembelajaran Berbasis Masalah Mathema: Journal Pendidikan Matematika.

Burhan Bungin. H.M (2011). Metode Penelitian Kuantitatif. Komunikasi, Ekonomi dan Kebijakan Publik serta Ilmu-ilmu lainnya. Jakarta: Kencana Prenama Media Group.

Puspaningtyas, N.D. (2019). Media Pembelajaran menggunakan video atraktif pada materi garis singgung lingkaran. Mathema journal Pendidikan Matematika.

Rhamdani, Mawar. (2012). Efektivitas penggunaan media pembelajaran e-learning berbasis web pada pembelajaran teknologi informasi. Yogyakarta.

Rohmah.L.(2016). Konsep E-learniing dan aplikasinya pada lembanaga pendidikan islam.

Rusefendi, E.T (2016). Pengantar kepada guru mengembangkan kompetensinya dalam pengajaran matematika. Bandung. Tarsito

Sugiyono (2016). Metode penelitian kombinasi. Bandung:alfabeta.

Yazdi, M. 2012.e-learning sebagau media pembelajaran interaktif berbasis teknologi informasi. Jurnal ilmiah foristek. 